\title{
PERENCANAAN DIMENSI SALURAN DRAINASE DALAM \\ MENANGGULANGI BANJIR PADA KOMPLEK PERUMAHAN BEA DAN \\ CUKAI RAWAMANGUN
}

Drs. Ir. LT. Simbolon dan Marta Deviana, S.Pd

\begin{abstract}
Abstrak
Perencanaan ini bertujuan untuk mendapatkan hasil perhitungan dimensi saluran drainase (saluran outlet) yang terdapat pada komplek perumahan Bea dan Cukai Rawamangun. Perencanaan dilakukan dengan mengambil data-data kewilayahan pada daerah komplek perumahan Bea dan Cukai Rawamangun. Untuk data curah hujan bulanan tahunan didapat dari tiga stasiun penakar curah hujan yaitu : stasiun curah hujan Rawamangun, BMG Kemayoran dan Halim Perdanakusuma. Metode yang digunakan adalah studi literatur dan observasi lapangan. Teknik perencanaan terdiri dari pengumpulan data-data perencanaan, pengolahan data, perhitungan dimensi drainase. Untuk menentukan dimensi saluran digunakan rumus Manning, sedangkan untuk intensitas curah hujan dianalisa dengan menggunakan rumus Gumbel. Hasil perhitungan berdasarkan analisa intensitas curah hujan dan kemiringan lereng daerah komplek perumahan Bea dan Cukai, maka didapat ukuran yaitu : dimensi saluran drainase I adalah 1,07 x 1,53 meter dengan bentuk trapesium, saluran drainase II adalah 1,22 × 2,00 meter dengan bentuk segi empat, saluran drainase III adalah 1,57 × 2,06 meter dengan bentuk trapesium. Untuk bak penampung (sumpit) didapat ukuran dimensi $40 \times 15 \times 5$ meter yang dihitung berdasarkan jumlah volume air yang masuk ke dalam bak dengan waktu 2 jam. Sedangkan pompa untuk menyedot air digunakan 2 unit pompa dengan kapasitas 125 liter/detik dengan type AP 100.100.61 EX.
\end{abstract}

\section{Pendahuluan}

Jakarta sebagai pusat kota di Indonesia, dimana teknologi berkembang demikian pesatnya selalu tak luput dari masalah banjir yang berkepanjangan. Jakarta yang dikenal sebagai kota yang sangat sibuk, seolah - olah lumpuh jika banjir datang.

Pedoman Penanggulangan Banjir Departemen Pekerjaan Umum menyatakan bahwa banjir adalah aliran yang relatif tinggi, dan tidak 
tertampung lagi oleh alur sungai atau saluran. Banjir dan genangan air yang terjadi akibat saluran tidak mampu menampung aliran air. Penyebab lainnya adalah masalah saluran drainase yang tidak berfungsi sebagaimana mestinya, adanya endapan-endapan lumpur dan sampah juga rusaknya saluran-saluran drainase yang ada.

Menurut Siswono Yudohusodo (1991) pada dasarnya dalam upaya pembangunan perumahan dan pemukiman harus tetap memperhatikan persyaratan minimum bagi perumahan dan pemukiman yang layak. Sasaran jangka panjang yang ingin dicapai adalah agar pada waktunya nanti, seluruh rakyat Indonesia dapat menghuni rumah yang layak dalam lingkungan yang sehat dan teratur.

Komplek perumahan Bea dan Cukai Rawamangun merupakan daerah yang memiliki permasalahan pada saluran drainase yang ada. Jalan utama pada komplek perumahan Bea dan Cukai ini sering mengalami banjir. Tidak hanya jalan, termasuk perumahan disekitarnya ikut terendam air. Waduk yang berfungsi sebagai kolam tampungan juga meluap, karena saluran drainase sebagai saluran pembuang air waduk sudah tidak memadai lagi.

Karena masalah banjir di wilayah ini sudah terjadi bertahun - tahun dan berbagai upaya telah dilakukan seperti pengerukan lumpur ternyata tidak membuahkan hasil, untuk itu maka diperlukan perencanaan ulang dimensi saluran drainase serta penggunaan instalasi pompa pembuangan.

Yang menjadi pertanyaan adalah bagaimana perencanaan saluran drainase guna mengatasi masalah banjir akibat terbatasnya ruang yang ada? bagaimana bentuk penanggulangan yang efektif dan tepat guna melihat kenyataan bahwa komplek perumahan Bea dan Cukai berada di daerah dataran rendah ? bagaimana sistem pemeliharaan saluran drainase pada komplek perumahan Bea dan Cukai ? bagaimana perencanaan dimensi saluran drainase dalam menanggulangi banjir pada komplek perumahan Bea dan Cukai Rawamangun?.

Berdasarkan masalah tersebut maka tujuan pokok perencanaan ini adalah untuk mendapatkan hasil rencana dimensi saluran drainase, bangunan pelengkap (sumpit) dan pompa penyedot air dalam upaya mengatasi genangan air dan banjir pada komplek perumahan Bea dan Cukai Rawamangun Jakarta Timur.

Perencanaan Dimensi Saluran Drainase Dalam Menanggulangi Banjir Pada Komplek Perumahan Bea dan Cukai Rawamangun (LT. Simbolon, Dosen Jurusan Teknik Sipil FTUNJ) 


\section{Pembahasan}

Drainase adalah prasarana yang berfungsi mengalirkan air permukaan ke badan air dan atau ke bangunan resapan buatan. Menurut Linsley dan Franzini (1995) drainase adalah istilah yang dipergunakan untuk sistem-sistem bagi penanganan air kelebihan. Tiga tugas pokok drainase adalah drainase hujan daerah perkotaan, drainase lahan, drainase jalan raya.

Prinsip dasar drainase adalah suatu cara untuk menyalurkan aliran air yang tidak berguna dari suatu tempat ke tempat lain melalui sarana saluran drainase yang ada agar air tidak menggenangi tempat tersebut dan agar tempat tersebut selalu dalam keadaan kering. Sasaran drainase tertuju pada bangunan-bangunan atau daerah-daerah serta obyek-obyek yang memerlukan sistem drainase yang baik, seperti : kota, pemukiman, jalan raya, jalan kereta api, gedung, lapangan olahraga, stadion, kolam renang, plasa, daerah pertanian, daerah yang selalu tergenang air, bendungan, dinding penahan tanah dan lain-lain.

Harsoyo Bangun dan I. Suhadi (1982) menjelaskan bahwa perbaikan drainase perlu dilakukan pada daerah-daerah : (1) daerah dengan muka air tanah yang tinggi sebagai akibat irigasi yang berlebihan atau rembesan air dari saluran, (2) daerah cekungan atau rawa dimana aliran air terhenti, (3) dataran rendah yang merupakan tempat penampungan aliran permukaan dari daerah sekitarnya yang lebih tinggi, (4) daerah sekitar muara sungai dan wilayah pantai yang tergenang air secara berkala oleh pengaruh pasang surut, (5) daerah pinggir sungai yang sering mengalami peluapan air sungai.

Berdasarkan penjelasan di atas, wilayah perumahan Bea dan Cukai dapat dikategorikan daerah cekungan atau dataran yang lebih rendah dari daerah-daerah disekitarnya yang menjadi tempat penampungan aliran permukaan yang berasal dari daerah sekitarnya yang lebih tinggi.

Perencanaan dalam arti seluas-luasnya adalah suatu proses mempersiapkan secara sistematis kegiatan-kegiatan yang akan dilakukan untuk mencapai sesuatu tujuan tertentu. Sedangkan perencanaan awal adalah mencakup kegiatan survey, penyelidikan dan desain. Dimensi menurut kamus umum Bahasa Indonesia adalah ukuran panjang, lebar, tinggi, dan luas.

Menurut Imam Subarkah (1980) perencanaan dimensi saluran drainase adalah sistem drainase hujan permukaan yang merupakan bagian dari sistem 
drainase keseluruhan yang melayani aliran maksimum dari hujan permukaan. Di dalam sistem ini termasuk parit dan saluran tepi jalan, gorong-gorong dan semua bangunan yang direncanakan dengan masa ulang 2 atau 5 tahun.

Kegiatan prarencana saluran dimaksudkan untuk menentukan bentuk atau jenis dari saluran yang direncanakan. Jenis saluran tersebut terdiri dari saluran tahan erosi, saluran peka erosi dan saluran berumput. Penentuan jenis dari saluran ini harus berdasarkan atas pertimbangan dari segi teknis dan ekonomi. Pada perencanaan saluran drainase ini direncanakan saluran drainase yang tahan erosi dengan bentuk saluran adalah trapesium. Selain itu dipakai juga saluran segi empat. Pemilihan didasari pada pertimbangan lokasi perencanaan, dimana lahan yang tersedia terbatas.

Selain itu diperlukan juga pompa untuk mempercepat pembuangan air dari bak penampung (sumpit) ke saluran outlet guna mengantisipasi banjir. Menurut Sularso dan Haruo Tahara (2000) pompa adalah suatu mesin atau alat yang digunakan untuk memindahkan zat cair dari satu tempat ke tempat lain. Sedangkan bangunan pelengkap dalam Standar Tata Cara Perencanaan Umum Drainase Perkotaan Departemen Pekerjaan Umum adalah bangunan yang dibuat dan berfungsi sebagai pelengkap sistem drainase perkotaan antara lain : gorong-gorong, pintu air, stasiun pompa, bak penampung, bak pengontrol dan bangunan terjunan.

\section{Metode Perencanaan}

Metode yang dilakukan adalah studi literatur dan observasi lapangan. Dari data yang diperoleh jumlah penduduk kelurahan Pisangan Timur adalah 46.401 jiwa dengan luas wilayah mencapai $1,80 \mathrm{~km}^{2}$. Luas rawa atau waduk mencapai 1,3 ha. Keadaan topografi secara umum terletak pada ketinggian 11 - 13 m diatas permukaan laut. Dahulu kawasan ini adalah rawa-rawa dengan jenis tanah lembut dengan kemiringan ke sebelah utara mengarah ke laut Ancol. Lokasi perumahan Bea dan Cukai berada pada ketinggian antara 11 $11,6 \mathrm{~m}$ diatas permukaan laut

Berdasarkan jumlah data curah hujan yang dapat dianalisa menurut metode Gumbel minimal 10 tahun pengamatan, dengan harga curah hujan

Perencanaan Dimensi Saluran Drainase Dalam Menanggulangi Banjir Pada Komplek Perumahan Bea dan Cukai Rawamangun (LT. Simbolon, Dosen Jurusan Teknik Sipil FTUNJ) 
tertinggi setiap tahunnya, maka data intensitas hujan yang digunakan sebanyak 14 tahun yakni dari tahun 1991 sampai dengan tahun 2004.

Teknik perencanaan dimensi saluran drainase adalah dengan menentukan prarencana saluran, mengolah data curah hujan maksimum tahunan dengan rumus Formula Rata-rata Aljabar, menganalisa besarnya curah hujan harian maksimum periode ulang $t_{r}$ tahun menggunakan rumus E. J. Gumbel, menghitung intensitas curah hujan menggunakan rumus Mononobe, menghitung waktu konsentrasi dengan menentukan koefisien kekasaran, menghitung debit rencana menggunakan metode Rasional, menghitung dimensi saluran menggunakan rumus Manning, menghitung daya tampung debit dari saluran, menghitung bangunan pelengkap (sumpit) serta kebutuhan pompa.

\section{Hasil Perencanaan}

Untuk keadaan sekarang ini saluran drainase I mempunyai dimensi 1,0 $\mathrm{x}$ 1,2 meter terbuat dari pasangan batu dengan bentuk trapesium. Saluran II mempunyai dimensi 1,5 x 1,5 meter terbuat dari pasangan batu dengan bentuk segi empat dan saluran III mempunyai dimensi $1,5 \times 1,8$ meter terbuat dari pasangan batu dengan bentuk trapesium. Untuk pompa berkapasitas 75 Itr/det dengan jumlah 1 unit,dengan dimensi sumpit $25 \times 15 \times 5$ m.

Saluran tersebut sudah tidak memenuhi kebutuhan untuk menampung dan mengalirkan air limpasan, sehingga jika musim hujan tiba maka terjadilah banjir dan genangan. Selain dikarenakan dimensi saluran yang tidak memadai lagi, hal ini terjadi juga disebabkan tingginya intensitas curah hujan dan luasnya daerah pengaliran disekitar lokasi perencanaan, dimana berdasarkan hasil analisa perhitungan intensitas curah hujan diperoleh data sebesar 190 $\mathrm{mm} / \mathrm{jam}$.

Maka berdasarkan perencanaan yang dilakukan diperoleh hasil perhitungan saluran I adalah 1,07 x 1,53 meter dengan bentuk saluran trapesium dan terbuat dari pasangan batu, saluran II adalah 1,22 × 2,00 meter 
dengan bentuk saluran segi empat dan terbuat dari pasangan batu dan saluran III adalah 1,57 x 2,06 meter dengan bentuk saluran trapesium dan terbuat dari pasangan batu.

Untuk mengantisipasi luapan pada waduk akibat aliran air dari saluran inlet, maka digunakan pompa penyedot air berkapasitas $125 \mathrm{ltr} /$ det dengan jumlah 2 unit, dengan bak penampung (sumpit) berdimensi $40 \times 15 \times 5 \mathrm{~m}$.

\section{Kesimpulan}

Berdasarkan hasil perencanaan dan perhitungan dimensi saluran drainase pada komplek perumahan Bea dan Cukai Rawamangun, maka didapatkan kesimpulan sebagai berikut :

1. Daerah komplek perumahan Bea dan Cukai merupakan daerah yang mempunyai intensitas curah hujan cukup tinggi, berdasarkan analisa data yang dilakukan mencapai $190 \mathrm{~mm} / \mathrm{jam}$. Tingginya intensitas yang terjadi ini tidak diukuti dengan saluran yang memadai, sehingga menyebabkan banjir pada saat hujan.

2. Dari perencanaan saluran yang dilakukan didapat perubahan dimensi saluran untuk saluran I sebelah kiri yang semula berdimensi 1,0 x 1,2 m diperbesar menjadi 1,07 x 1,53 m. Juga untuk saluran II sebelah kanan dari 1,5 x 1,5 m diperbesar menjadi 1,22 x 2,0 m dan saluran III dari 1,5 $\mathrm{x}$ 1,8 $\mathrm{m}$ diperbesar menjadi $1,57 \times 2,06 \mathrm{~m}$.

3. Untuk mencegah terjadinya peluapan pada waduk maka digunakan pompa penyedot air disertai bak penampung (sumpit).

\section{Saran}

Berdasarkan kesimpulan yang telah diuraikan, maka dapat diajukan saran-saran sebagai berikut :

1. Dalam perencanaan dimensi saluran drainase pada suatu daerah, hendaknya dibuat berdasarkan debit rencana yang mungkin terjadi. Untuk itu disarankan untuk menganalisa intensitas curah hujan yang terjadi sehingga akan diperoleh hasil perhitungan dimensi saluran drainase yang dapat memenuhi kebutuhan.

Perencanaan Dimensi Saluran Drainase Dalam Menanggulangi Banjir Pada Komplek Perumahan Bea dan Cukai Rawamangun (LT. Simbolon, Dosen Jurusan Teknik Sipil FTUNJ) 
2. Untuk lancarnya kerja pompa diperlukan pemeliharaan secara berkala terhadap pompa yang ada. Dan juga pemeliharaan terhadap bak penampung (sumpit).

3. Perlunya penyuluhan kepada masyarakat khususnya pada daerah yang dilalui saluran supaya masyarakat tidak membuang sampah pada sembarang tempat yang dapat mengakibatkan daya tampung saluran menjadi berkurang.

\section{Daftar Pustaka}

Bangun, Harsoyo, dan I. Suhadi. Irigasi dan Drainase I. Jakarta : Departemen Pendidikan dan Kebudayaan, 1982.

Badudu, J.S, dan Sultan M.Zain. Kamus Umum Bahasa Indonesia. Jakarta : Pustaka Sinar Harapan, 1996.

Chow, Ven Te., dan E.V. Nensi Rosalina. Hidrolika Saluran Terbuka. Jakarta : Erlangga, 1992.

Departemen Pekerjaan Umum. Pedoman Penanggulangan Banjir. Jakarta : Direktorat Jendral Pengairan, 1986.

Departemen Pekerjaan Umum. Drainase. Jakarta : Direktorat Pekerjaan Umum, 1997.

Departemen Pekerjaan Umum. Standar Tata Cara Perencanaan Hidrologi dan Hidrolika Untuk Bangunan Sungai SNI 1724-F. Jakarta : Badan Penerbit PU, 1989.

Departemen Pekerjaan Umum. Standar Tata Cara Perencanaan Umum Drainase Perkotaan SK SNI T-07-1990-F. Jakarta : Badan Penerbit PU, 1990.

Departemen Pekerjaan Umum. Standar Metode Menghitung Design Flood. Jakarta : Badan Penerbit PU, 1990.

Departemen Pekerjaan Umum. Standar Tata Cara Perencanaan Umum Drainase Perkotaan SK SNI 03-3424-1994. Jakarta : Badan Penerbit PU, 1994.

Dewan Standarisasi Nasional. Standar Tata Cara Perencanaan Drainase Permukaan Jalan SK SNI 03-3424-1994. Jakarta : Badan Penerbit PU, 1994.

Hendarsin, Shirley, L. Perencanaan Teknik Jalan Raya. Bandung : Politeknik Negeri Bandung, 2000.

Loebis, Joesron. Banjir Rencana Untuk Bangunan Air. Jakarta : Badan Penerbit PU, 1992.

Linsley Ray. K dan Joseph B. Franzini. Teknik Sumber Daya Air Jilid 2. Jakarta : Erlangga, 1995.

Proyek Penyusunan Perencanaan dan Buku-buku Pedoman Pengairan Departemen Pekerjaan Umum. Pedoman Perencanaan Saluran Terbuka. Jakarta : Badan Penerbit PU, 1972. 
Pangaribuan, YP. Aliran Melalui Saluran Terbuka. Jakarta : Erlangga, 1986.

Ramli, Agus. Studi Perencanaan Dimensi Saluran Drainase Perkotaan Sebagai Usaha Penanggulangan Banjir. Jakarta : Universitas Negeri Jakarta, 2002.

Sukarto, Haryono. Drainase Perkotaan. Jakarta : Badan Penerbit PU, 1999.

Sudarso, Suyono. Pengembangan Wilayah Sungai. Jakarta : Badan Penerbit PU, 1978.

Sutanto dan Sidharta Kamarwah. Pedoman Drainase Jalan Raya. Jakarta : Penerbit UI, 1987.

Subarkah, Imam. Hidrologi Untuk Perencanaan Bangunan Air. Bandung : Idea Dharma, 1980.

Sosrodarsono, Suyono. Ir., dan Kensaku Takeda. Hidrologi Untuk Pengairan. Jakarta : Pradnya Paramita, 1993.

Sularso, dan Haruo Tahara. Pompa dan Kompresor. Jakarta : Pradnya Paramita, 2000.

Taslani. Analisa Efisiensi Karakteristik Pompa Terhadap Putaran Sidu. Jakarta : Universitas Bung Karno, 2003.

Tjokroamidjojo, Bintoro. Perencanaan Pembangunan. Jakarta : Gunung Agung, 1979.

Yudohusodo, Siswono. Rumah Untuk Seluruh Rakyat. Jakarta : Yayasan

Padamu Negeri, 1991.

Perencanaan Dimensi Saluran Drainase Dalam Menanggulangi Banjir Pada Komplek Perumahan Bea dan Cukai Rawamangun (LT. Simbolon, Dosen Jurusan Teknik Sipil FTUNJ) 